\title{
SHIPBOARD WEIGHING SYSTEM OF CONTAINERS
}

\section{СУДНОВА СИСТЕМА ЗВАЖУВАННЯ КОНТЕЙНЕРІВ}

\author{
A.K. Sandler, assistant professor, O.V. Drozd, assistant professor \\ А.К. Сандлер, доиент, О.В. Дрозд, доцент \\ Національний університет «Одеська морська академія», Україна \\ National University «Odessa Maritime Academy», Ukraine
}

\begin{abstract}
According to IMO studies, numerous crash cases with container vessels were caused precisely by the fact that the weight of the containers was incorrectly indicated. As a result, cargo, containers and vessels were damaged. Statistics show that there are numerous cases when cargo containers arrive from the ship to the sea. To find ways to improve the situation with heavy control operations at container terminals, the structures of the most common types of vagometric devices were analyzed.

Under the prevailing conditions, it was expedient to develop a new circuit design solution of a gauge device. It was assumed that a constructive implementation based on fiber-optic and electromechanical elements should provide a measuring device:

- the possibility of taking into account when weighing the actual center of gravity of the container with the load;

- absence of additional information channels and reloading operations during weighing;

- lack of dependence on climatological factors;

- high sensitivity and precision preservation, as well as simplicity and reliability of circuit design solutions of known types.

For solving the problem, a scheme of a weight-control device is proposed. The proposed system for weighing containers is characterized in that the base is movable and driven along the guide along the height of the container row by a linear electric motor, the weight of the container is transmitted to the sensitive element by means of a beam with a reverse spring and an eccentric pressing on a stem which interacts with the sensitive an element of aluminum ox nitride, connected to fiber optic fibers, a weight gauge spring and a terminal switch that controls a linear electric motor.

The application of the proposed system of weighing containers, in addition, will increase the safety and efficiency of technological weight control processes in general.
\end{abstract}

Keywords: system, cargo, container. 
Постановка проблеми в загальному вигляді та їі зв'язок з важливими науковими та практичними задачами

Зважування всіх контейнерів стане в ближньому майбутньому реальністю для термінальних операторів. Яке ж підгрунтя для впровадження правил щодо зважування контейнерів вимагає International Maritime Organization (IMO)? IMO, по-перше, вважає найбільш доцільним запобігти аварійним ситуаціям 3 морськими суднами, які $є$ наслідком втрати контейнеровозами остійності. За результатами досліджень IMO, чисельні аварії з контейнерними суднами були викликані саме тим, що неправильно була вказана вага контейнерів. Внаслідок чого вантаж, контейнери та судна отримали пошкодження (рис. 1).

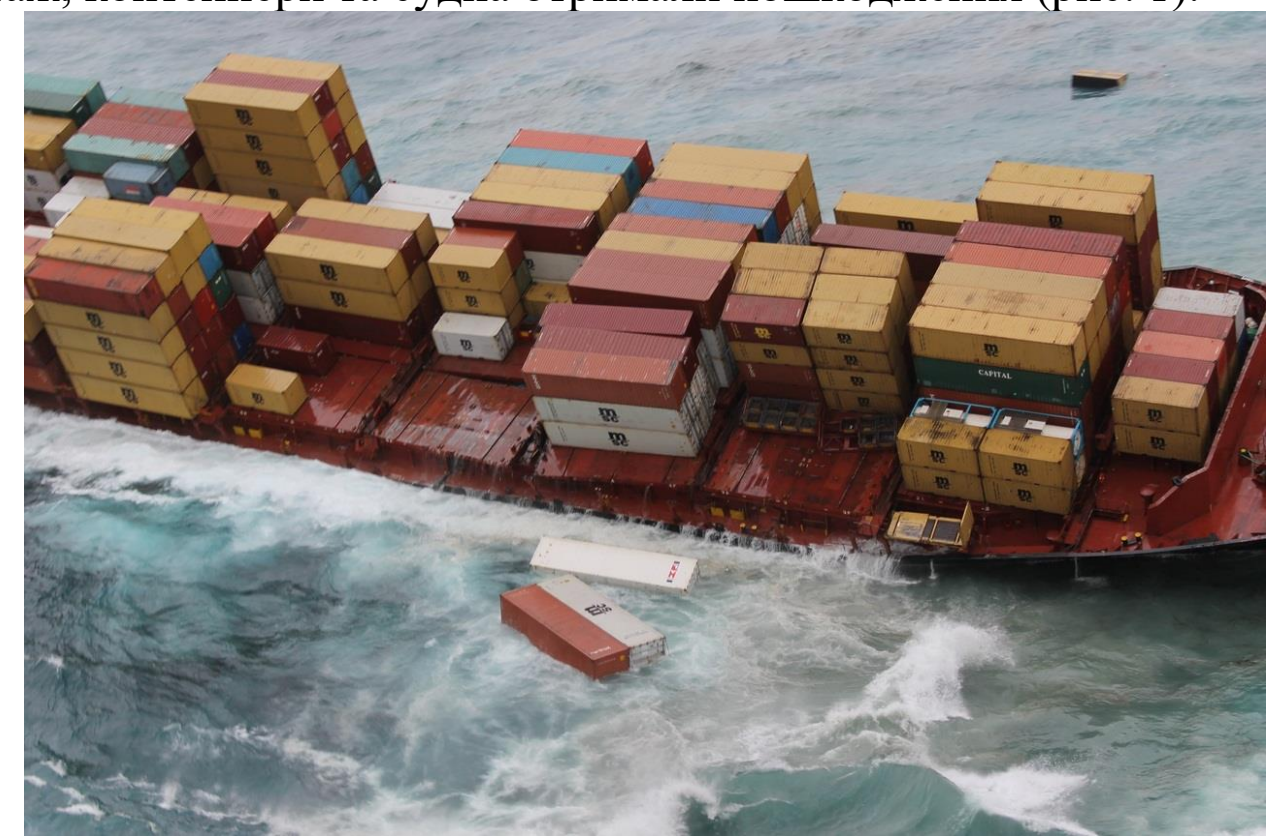

Рис. 1. Аварія контейнеровоза

Статистика свідче про чисельні випадки, коли контейнери з вантажами потрапляють 3 судна до моря. Таким чином, у IMO були всі підстави обговорити нові правила зважування та запровадити їх як обов'язкові.

Було здійснено два багатофакторних дослідження. Головне дослідження було проведено університетом Jadehochschule в 2012 та 2013 роках. Зважувались (випадкова вибірка) більш як 6500 контейнерів на Одеському контейнерному терміналі. Отримані такі результати:

1. Середне відхилення за вагою склало $3,8 \%$;

2. $15 \%$ контейнерів відрізнялись за вагою в ту чи іншу сторону на одну тонну;

3. 0,5 \% контейнерів відрізнялись за вагою більш чим на 10 тонн.

Друге дослідження було проведено у 2010 році World Shipping Council та International Chamber of Shipping. Результати цього дослідження продемонстрували, що загальна вага вантажу на борту судна практично регулярно перевищує заявлену на $3 \ldots 7 \%$, а в деяких особливо небезпечних випадках навіть на $10 \%[1,2,3]$. 
Аналіз останніх досягнень та публікацій, в яких розпочато розв `ззвання даної проблеми та висвітлювання нерозв`язаних раніше частин загальної проблеми

Для пошуку шляхів поліпшення ситуації з вагоконтрольними операціями на контейнерних терміналах були проаналізовані конструкції найпоширеніших типів вагометричних пристроїв.

Відома система зважування контейнерів складається з вагової платформи та динамометричного чутливого елементу між платформою та вантажним гаком (рис. 2) [4].

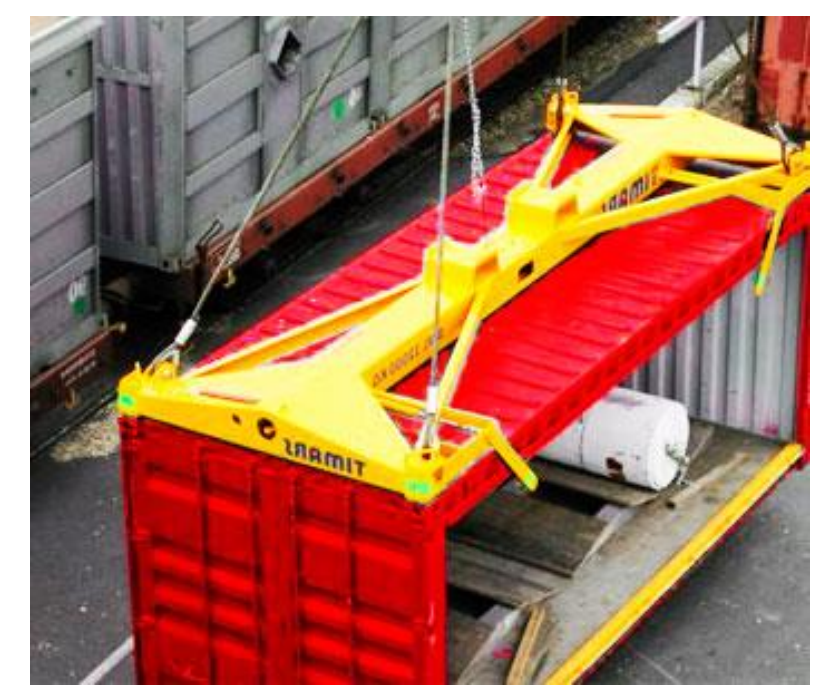

Рис. 2. Вагова платформа з динамометром

Недоліки пристрою, які обумовлені застосуванням вагової платформи та динамометричного чутливого елементу:

- неможливість урахування при зважуванні дійсного центру ваги контейнера 3 вантажем;

- необхідність наявності додаткового каналу передачі інформації «вагисудно»;

- залежність достовірності виміру від кліматологічних умов навколишнього середовища.

У меншій мірі експлуатаційні та конструктивні фактори впливають на характеристики системи зважування контейнерів, яка складається з основи, плити фундаментної, чутливого елементу з кріпленням та вагової платформи (рис. 3) [5].

Недоліки пристрою, які обумовлені застосуванням вагової платформи:

- необхідність додаткової перевантажувальної операції «берег-ваги-судно»;

- необхідність наявності додаткового каналу передачі інформації «вагисудно»;

- залежність достовірності виміру від кліматологічних умов навколишнього середовища. 


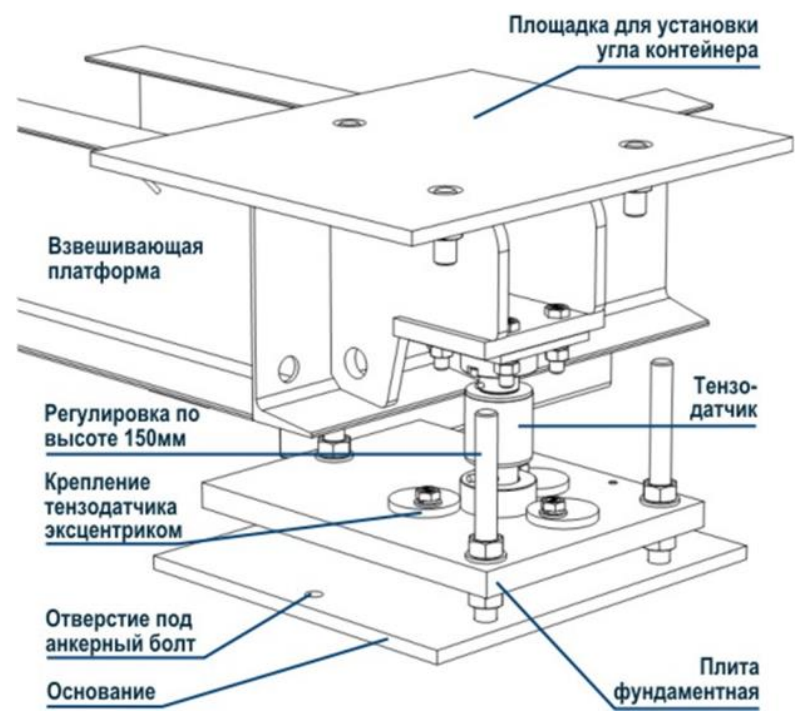

Рис. 3. Стаціонарна система зважування контейнерів

\section{Формулювання мети статі (постановка задачі)}

В умовах, що склалися, доцільною стала розробка нового схемотехнічного рішення вагометричного пристрою. Передбачалося, що конструктивне виконання на основі волоконно-оптичних та електромеханічних елементів повинне забезпечити вимірювальному пристрою:

- можливість урахування при зважуванні дійсного центру ваги контейнера 3 вантажем;

- відсутність додаткових інформаційних каналів та перевантажувальних операцій при зважуванні;

- відсутність залежності від климатологічних чинників;

- збереженість високого рівня чутливості та точності, а також простоти та надійність схемотехнічних рішень систем відомих типів.

Для розв 'язування поставленої задачі запропонована схема вагометричного пристрою.

Виклад матеріалу дослідження 3 обгрунтуванням отриманих наукових результатів

Суть запропонованого схемотехнічного рішення пояснюється кресленням (рис. 4), де зображено система зважування контейнерів, що складається 3 чотирьох комплектів, змонтованих по кутах кожного контейнерного ряду. 


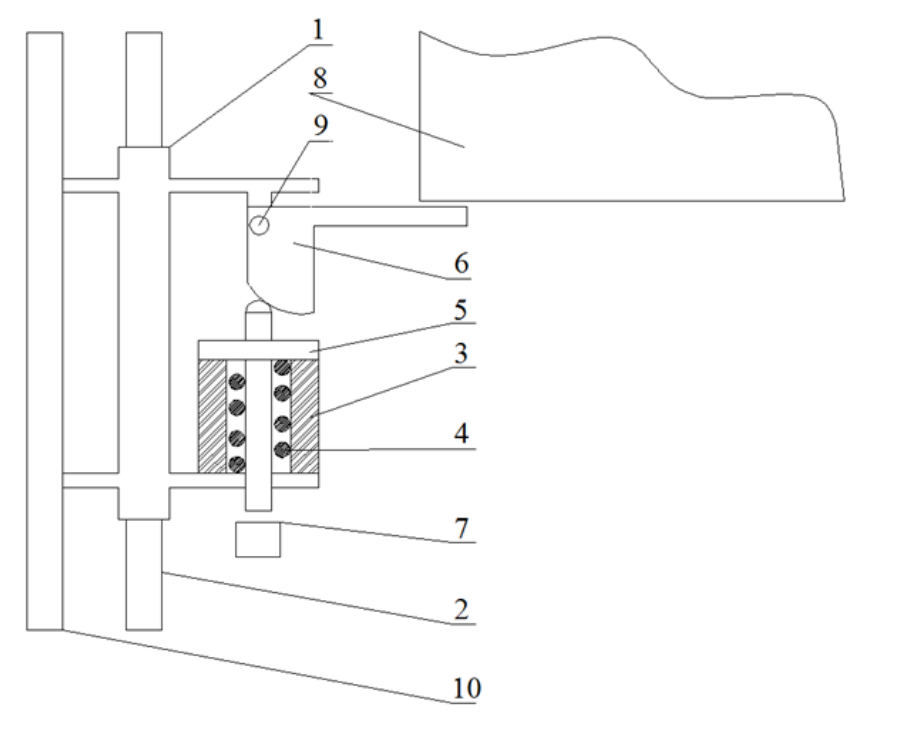

Рис. 4. Суднова система зважування контейнерів: 1 - основа; 2 - напрямна; 3 - чутливий елемент з оксинітриду алюмінію з волоконними світловодами; 4 - калібровочна пружина; 5 - иток; 6 - балка з ексиентриком; 7 - кінцевий вмикач; 8 - контейнер; 9 - зворотна пружина; 10 - лінійний електродвигун.

Кожен з комплектів являє собою основу 1 , яка рухається уздовж напрямної 2. На основі закріплені чутливий елемент 3 оксинітриду алюмінію 3 волоконними світловодами 3 , калібровочна пружина 4 , балка з ексцентриком 6 , кінцевий вмикач 7 та зворотна пружина 9. Шток 5 знаходиться у механічному зв язку 3 чутливим елементом, калібровочною пружиною та балкою 3 ексцентриком та зворотною пружиною. Рух основи уздовж напрямної забезпечує лінійний електродвигун 10.

При опусканні по ряду контейнера 8 , він приводить до руху балку 3 ексцентриком, який тисне на шток. Шток тисне на чутливий елемент та калібровочну пружину. Чутливий елемент 3 оксинітриду алюмінію деформується та в ньому відбувається порушення умов повного внутрішнього відбивання світла, що надходить 3 волоконних світловодів [6].

Величина зниження інтенсивності світлового випромінювання внаслідок деформації буде пропорційна вазі контейнера. Отриманий сигнал надходить безпосередньо до суднової інформаційно-вимірювальної системи.

Після проходження контейнера зони контакту з балкою, зворотна пружина повертає іï в початкове положення, а шток у крайньому нижньому положенні вмикає кінцевий вмикач. 3 кінцевого вмикача надходить сигнал до лінійного електродвигуна. Останній переміщає основу до позиції, що відповідає наступному шару контейнерів у ряді.

Для здійснення винаходу застосовано комбінацію оптікомеханічних елементів.

У статичному режимі (перед початком вантажної операції) на опорі встановлюєть відповідна калібруюча пружина, яка відповідає вазі та типу контейнерів які будуть завантажуватися у відповідний ряд. Також виконується калібрування оптичної складової системи у відсутності навантаження. 
У динамічному режимі (режим вантажної операції) відбувається При опусканні по ряду контейнера 8 , він приводить до руху балку з ексцентриком, який тисне на шток. Шток тисне на чутливий елемент та калібровочну пружину. Чутливий елемент з оксинітриду алюмінію деформується та в ньому відбувається порушення умов повного внутрішнього відбивання світла, що надходить 3 волоконних світловодів [6, 7, 8, 9]. Величина зниження інтенсивності світлового випромінювання внаслідок деформації буде пропорційна вазі контейнера. Отриманий сигнал надходить безпосередньо до суднової інформаційно-вимірювальної системи.

Після проходження контейнера зони контакту з балкою, зворотна пружина повертає їі в початкове положення, а шток у крайньому нижньому положенні вмикає кінцевий вмикач. 3 кінцевого вмикача надходить сигнал до лінійного електродвигуна. Останній переміщає основу до позиції, що відповідає наступному шару контейнерів у ряді.

Для визначення точної ваги контейнера, з урахуванням дійсного центру ваги вантажу, суднова інформаційно-вимірювальна система опрацьовує сигналу з усіх чотирьох чутливих елементів комплекту.

Таким чином, відбувається повний цикл системи вимірювання ваги контейнера.

\section{Висновки та перспектива подальшої роботи за даним напрямком}

Запропонована суднова система зважування контейнерів, відрізняється тим, що основа $\epsilon$ рухомою та приводиться до руху по напрямним уздовж висоти контейнерного ряду лінійним електродвигуном, до чутливого елементу передається дія ваги контейнера за допомогою балки зі зворотною пружиною та ексцентриком, що тисне на шток, який взаємодіє 3 чутливим елементом 3 оксинітриду алюмінію, 3'єднаним 3 волоконними світловодами, ваговою калібровочною пружиною та кінцевим вмикачем, який керує лінійним електродвигуном [10].

Таким чином, в розробленому пристрої комбінація електромеханічних та волоконно-оптичних елементів забезпечує:

- здійснення вагового контролю контейнерів безпосередньо під час вантажних операцій;

- врахування й компенсацію впливу гідрометеорологічних чинників, що впливають на точність вагоконтрольних операцій;

- постійну присутність вагоконтрольного комплексу на борту судна;

- зниження витрат та часу на вагоконтрольні операції.

Застосування запропонованої системи зважування контейнерів, крім того, дозволить підвищити безпеку і ефективність технологічних вагоконтрольних процесів в цілому.

\section{ЛІТЕРАТУРА}

1. Весы крановые. [Электронный ресурс]. - Режим доступа: http://www.torgtehnika.com.ua/vesi-kranovie/blog.html 
2. Нікольський В. В., Нікольський М. В., Накул Ю. А. Система підтримки прийняття рішення по навантаженню великотоннажного контейнеровоза. // Наукові праці: Науково-методичний журнал. - Миколаїв: Вид-во ЧНУ ім. Петра Могили. - 2016. - Вип. 271. - Т. 283. Комп’ютерні технології. -С. 60 $-63$.

3. Шмекер К. Взвешивание контейнеров по требованиям IMO и его возможные последствия / К. Шмекер // Порты Украины, № 07(139). - 2014 [Электронный ресурс]. - Режим доступа: http://portsukraine.com /node/ 3776.

4. Крановые весы - характеристики, устройство и применение - Режим доступа: http://promplace.ru/kranovie-vesi-harakteristiki-ustrojstvo-i-primenenie466.htm.

5. Контейнерные весы. [Электронный ресурс]. - Режим доступа: http://www.metra.ru /catalogue/ bolshegruznye-vesy/konteinernye-vesy.html.

6. AION прозрачный алюминий - Transparent Aluminum Oxynitride. [Электронный ресурс]. - Режим доступа: http://www.sciencedebate2008.com/ unusual-aluminum/.

7. Сандлер А.К. Волоконно-оптический акселерометр для диагностирования судовых газовых турбин. //Автоматика-2012: XIX Міжнародна конференція 3 автоматичного управління, 26-28 вересня 2012 р.: матеріали конференції K.: HУXT. - 2012. - C. 336.

8. Сандлер А.К., Логишев, И.В. Разработка волоконного акселерометра для контроля высокочастотной вибрации судовых механизмов. // Річковий та морський флот: експлуатація та ремонт: матеріали науково-технічної конференції- Одеса: НУ «ОМА». - Т.2. - 2017. - С. 14 - 17.

9. Сандлер А.К., Логишев, И.В., Сандлер, А.А. Инвариантный волоконный акселерометр. //Енергетика судна: експлуатація та ремонт: матеріали науково-технічної конференції - Одеса: ОНМА. - 2011. - С. 277 -279.

10.Сандлер А.К., Дрозд О.В. Суднова система зважування контейнерів. Деклараційний патент України № 117146, МПК (2006) G01G 15/00, G01G 17/00. - заявл. 27.03.2017. // Опубл. 12.06.2017, бюл. № 11/2017. 